\title{
REDUCING THE IMPACT OF FRUIT SPOILAGE DISEASES ON NEW ZEALAND'S FRUIT EXPORT INDUSTRIES
}

\author{
R.M. BERESFORD \\ HortResearch, Mt Albert Research Centre, Private Bag 92169, Auckland \\ Corresponding author: rberesford@hortresearch.co.nz
}

\begin{abstract}
Fungal plant pathogens that cause fruit spoilage affect New Zealand's fruit industries through direct losses, disease control costs and market uncertainty costs. Market access costs also occur related to the use of certain agrochemicals and to perceived biosecurity risks from the presence of specific organisms on exported fruit. A small number of pathogens cause a diverse range of diseases affecting many different fruit crops. Fruit rot diseases are often difficult to control, difficult to understand and difficult to predict. Recurring research issues include unclear taxonomy and cryptic fungal life cycles. Determining when infection occurs and what factors affect it is difficult because infections that establish during fruit development often remain symptomless until ripening occurs. Lessening the impact of these diseases requires an ongoing specialist research capability working in conjunction with industry partners and supported by consistent levels of funding.
\end{abstract}

Keywords: fungal pathogens, fruit rot, cost impacts, disease management, biosecurity.

\section{INTRODUCTION}

New Zealand's fruit exports are expanding (Fig. 1) and have a current value of \$NZ 1.2 billion for fresh fruit, \$NZ 302 million for wine and \$NZ 84 million for processed fruit (Kerr et al. 2004). As in all biological production systems, potential earnings can be constrained by a wide range of factors, including currency exchange rate, market access issues, disorders affecting quality, pests and diseases. This paper focuses on fruit spoilage diseases and discusses their economic impacts and some key aspects of the fungal pathogens that cause them. It explores the main research issues that need to be addressed in order to reduce the impact of these diseases.

\section{Direct costs}

\section{IMPACTS OF FRUIT DISEASES}

The direct losses that fungal fruit rot pathogens cause have their most obvious economic effects at the individual orchard level, but in some years region-wide losses can occur. While reliable data on fruit rot losses may be readily available from packhouse records, these data do not include diseased fruit that were lost during growing and picking. In-orchard losses may be very high, although orchard data on fruit rot incidence is difficult to obtain. In a study of brown rot (Monilinia fructicola) incidence in nectarine and peach orchards in 2001-2002, it was found that losses on individual orchards could be very severe, ranging from 0 to $92 \%$, with an average of $37 \%$ (Elmer et al. 2002).

In general, incidence of fruit rots of $0.1-1.0 \%$ is not economically important, but as incidence increases from 1 to $10 \%$ the economic impact changes from unimportant to severe. The greatest impact of fruit rots on orchard economics is in the packhouse. Fruit picking and grading is the greatest single cost component in many fruit industries (Beresford \& Manktelow 1994) and thus an incidence of rots high enough to slow 
harvesting and packhouse operations causes large economic losses. Rots that develop in packed fruit tend to be more costly than those that develop in the orchard because labour costs for repacking are very high. If rots appear offshore, then the costs are greater still. Most industries are structured so that growers are directly responsible for the costs of product failure after fruit has left the orchard.

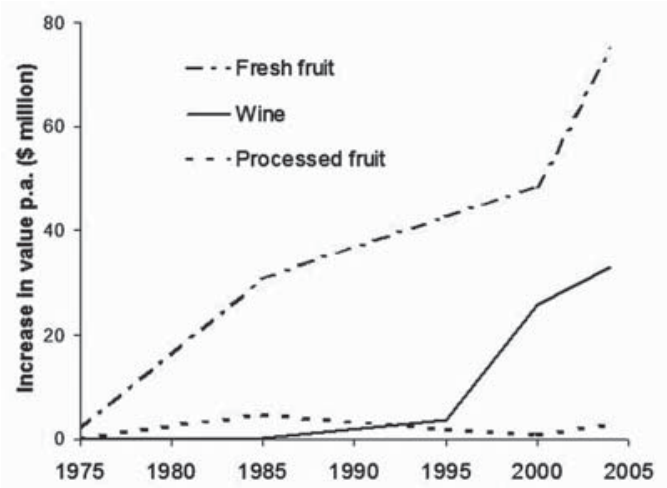

FIGURE 1: Average annual rate of increase in value of New Zealand fresh fruit, processed fruit and wine exports during the period 1975-2004. Data interpreted from Kerr et al. 2004.

For a processed crop, such as wine grapes, direct losses caused by fruit rots would appear simpler to quantify. However, with botrytis bunch rot (caused by Botrytis cinerea) infection levels as low as 5\% in an individual vineyard can lead to rejection of grapes for wine making because of the adverse effects on wine quality of enzymes produced during infection.

Wine industry data indicate that botrytis bunch rot may cause direct losses of $5-10 \%$ of the national crop in some years. In the 2002 vintage, grape losses were estimated to be \$NZ 9.9 million with \$NZ 49 million potentially lost in wine revenue. The average loss in income to growers is regularly more than \$NZ 1100/ha, despite over \$NZ 2.5 million per annum being spent nationally on fungicides (Philip Manson, New Zealand Winegrowers, pers. comm.).

\section{Disease control costs}

Fungicides have been an extremely cost-effective tool for management of many fruit diseases. Fungicide chemical and spraying costs, even for crops that are highly susceptible to a key disease, such as brown rot (caused by Monilinia fructicola) in stonefruit or black spot (caused by Venturia inaequalis) in apples, are usually less than $10 \%$ of production costs. Given that $100 \%$ losses would frequently occur for these crops without fungicides, this is a very cost-effective approach to disease management. However, the negative effects of agrochemical use include loss of market premium or no market access for fungicide-treated fruit. So dependence on fungicides for disease management is a strategy that has a limited future. The primary focus of recent fruit disease research has been the development and integration of non-chemical disease management technologies, such as biological control and elicitation of plant defences.

Some non-fungicide control methods are well known, such as crop sanitation to remove infected mummified fruit from trees. Even though these methods are often more complicated, more costly and less effective than fungicides, they are likely to become increasingly important for disease management in the future. For some fruit diseases, 
e.g. botrytis storage rot of kiwifruit, cultural methods, such as management of leaf canopy density, have been important for a long time, since there has always been a need to avoid late-season chemical applications to meet export market residue requirements.

\section{Market uncertainty costs}

Product reputation is at stake when fruit rots appear in fruit in the market place, but the impact of this is usually difficult to quantify. When gold kiwifruit was introduced into the export market in 2001 and 2002 there was a high incidence of product breakdown in the European market, about $30 \%$ of which was attributable to rots. The direct losses onshore and offshore were about \$NZ 80 million, but because prices were lowered to compensate for loss of customer confidence, this caused a further \$NZ 14 million loss (S. Kay, pers. comm.).

\section{Market access and biosecurity-related costs}

Use of certain agrochemicals in disease control spray programmes can restrict access of fruit to certain markets. This is becoming important in determining fungicides that can be used in spray programmes and for driving the development of non-chemical disease controls.

Increasingly, fruit pathogens are the subject of quarantine-related market access issues and this can be expected to increase in the future. A well known example is the inability of the New Zealand apple industry to export apples to Australia because of the presence of fire blight (caused by Erwinia amylovora) in New Zealand. In addition, European canker (caused by Neonectria galligena) is now the subject of market access negotiations with Australian authorities because it is seen as a possible risk to Australian plant health.

There is also the potential for some pathogens that have been recorded in New Zealand on particular hosts, but not recorded on those hosts in other countries, to become market access issues. The reliability of some pathogen records in New Zealand can be called into question. There may be records where pathogens were misidentified and others where saprophytic fungi have been included in pathogen lists. Such mistakes are a potential liability for New Zealand's fruit industries and emphasize the need for rigorous science to ensure accurate identification and appropriate pathogenicity testing. A strong taxonomic capability is required with modern DNA-based techniques to ensure that new records are accurate, that pathogens are correctly identified and that old records are corrected, where cultures or specimens are available.

\section{Impacts of fruit diseases on industry research priorities}

The sporadic nature of fruit rot outbreaks tends to be matched by sporadic funding for research on fruit diseases. A familiar pattern to plant disease researchers is for a high incidence of a fruit rot disease to occur in a cluster of orchards in a particular season, causing some economic loss and gaining the attention of an industry research committee. In the following season, a small amount of money is made available for a research project to investigate the problem. Often the conditions in the following seasons are different and the same disease problem does not reappear. The project is then completed and the funding withdrawn until the year after the next fruit rot outbreak occurs. To avoid such ineffective and wasteful research a strategic approach is required to quantify the ongoing losses from the disease problem and plan a research objective and funding regime that is adequate to deliver useful solutions.

However, there are some good examples that show how sustained and rigorously directed industry-funded research has solved complex fruit disease problems, for example, the botrytis management system developed in the kiwifruit industry during the 1990s (Manning \& Pak 1993). This and other examples of successful fruit disease research have usually involved a strategic and long-term view of the problem and a combination of both industry and government funding over a 5-10 year period.

\section{FRUIT PATHOGENS - THE USUAL SUSPECTS}

A few key fungal pathogens affect a wide range of fruit crops (Table 1). The diseases they cause in individual crops can appear quite disparate, depending on the production system and postharvest procedures and on the way the disease develops in relation to 
the purpose the crop is used for. For example, $B$. cinerea causes a pre-harvest bunch rot in wine grapes that increases rapidly in the vineyard through successive cycles of reinfection. However, in kiwifruit $B$. cinerea causes a post-harvest rot in cool storage that results from contamination of the picking wound at harvest by conidia from necrotic tissue in the vines. Research on a given pathogen often tends to occur separately in different industries. In some cases there could be benefits from coordination between industries to identify common factors that drive a single pathogen causing different diseases in different crops.

TABLE 1: Key genera of fruit pathogens and the crops in which they cause economic losses.

\begin{tabular}{|c|c|c|c|c|c|c|c|c|c|}
\hline Pathogen genera/species & 牚 & $\frac{\tilde{\alpha}}{\frac{2}{2}}$ & 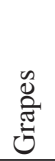 & 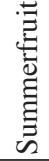 & 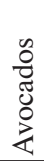 & $\underset{\infty}{\stackrel{\Xi}{\Xi}}$ & $\stackrel{\mathscr{E}}{\Xi}$ & 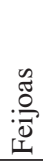 & 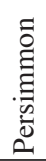 \\
\hline Glomerella/Colletotrichum & & + & & & + & + & & + & \\
\hline Botrytis cinerea & + & + & + & & & + & + & & + \\
\hline Phomopsis & + & & + & & & & & & \\
\hline Botryosphaeria & + & + & & & + & & & & \\
\hline Cryptosporiopsis & + & & & & & & & & + \\
\hline Elsinoe & & + & + & & & & & & \\
\hline Penicillium & & + & & & & & + & & \\
\hline Monilinia & & & & + & & & & & \\
\hline
\end{tabular}

\section{FRUIT DISEASE RESEARCH REQUIREMENTS}

There are several key attributes of fruit rot diseases caused by fungal pathogens that drive research requirements. These include cryptic life cycles, latent infection, symptom expression during fruit ripening and the sporadic nature of disease outbreaks.

Cryptic life cycles occur with many fruit pathogens, creating difficulties in determining where the pathogens perrenate and what the sources of inoculum are for fruit infection. While it is often assumed that inoculum originates within each orchard, the difficulty in detecting the pathogens means it is difficult to quantify possible inoculum sources from external sources. DNA-based techniques have great potential to enhance this type of research. An improved understanding of pathogen biology and sources of inoculum is essential to identify opportunities for disease management. For example, inoculum monitoring in kiwifruit orchards has given the orchardists some ability to predict when their crops have a high risk of botrytis storage rot development. Clearly, development of low-cost methods to detect and quantify inoculum in other crops should be a high research priority.

Latent infection is a common characteristic of fungal fruit pathogens. A pathogen initiates fruit infection in the orchard during the season, but the fruit remain symptomless until ripening occurs. Methods to detect and quantify latent infection to assist with disease risk assessment are another research priority. Techniques for assessment of latent infection for botrytis bunch rot in grapes and brown rot in stone fruit are being developed (P.A.G. Elmer, pers. comm.), but these are not yet simple or cheap enough to be routinely used within these industries.

Symptom expression during fruit ripening is another characteristic of fungal fruit rots on which research needs to focus. Understanding how disease development is linked to the ripening process is crucial to managing fruit rot risks in the market place and for identifying new strategies of disease management. This requires an understanding of 
the physiological triggers within the fruit that lead to rot development and their genetic control.

Sporadic fruit rot outbreaks probably result from the requirement that several different factors need to be simultaneously conducive for disease development before a widespread disease outbreak will occur. Likely risk factors include varietal susceptibility, weather suitable for infection or inoculum build-up in the orchard, injury to fruit through handling damage or weather conditions, and adverse storage conditions. Fruit rot prediction systems tend to rely on monitoring a single factor, such as weather or some measure of inoculum. However, this may only allow accurate prediction some of the time and may therefore be unreliable for most of the time. Appropriate statistical techniques need to be used with sound data on pathogen, host, environment and crop management to develop robust and accurate predictive systems.

\section{CONCLUSIONS}

Fungal fruit rot diseases are a complex and ongoing problem for fruit exporting industries. Changes to any aspect of orchard management, chemical use, harvesting procedure, storage conditions or market requirements are often associated with new disease problems or new aspects to old problems. Reducing the impact of these diseases on New Zealand's horticultural exports requires a strong science capability working in conjunction with informed industry partners to deliver lasting solutions. There is the need for both strategic research to develop new and innovative approaches to prevent these diseases as well as reactive research to tackle problems as they arise. A wide range of scientific capability is required, including classical fungal biology, taxonomy and plant pathology in conjunction with increasing use of DNA techniques and statistical methods to identify factors that can be reliably used in disease prediction systems.

\section{REFERENCES}

Beresford RM, Manktelow DWL 1994. Economics of reducing fungicide use using weather-based disease forecasts for control of Venturia inaequalis in apples. New Zealand Journal of Crop and Horticultural Science 22: 113-120.

Elmer PAG, Wood PN, Marsden RS, Parry FJ, Trotter I, Fraser J, McLaren G, Weaver E 2002. New tools for predicting and controlling postharvest rots of summerfruit 2001/02. Report to Agmardt, Summerfruit New Zealand and Heinz-Wattie NZ Ltd. HortResearch Client Report No. 2003/47. 54 p.

Kerr JP, Hewett, EW, Aitken AG 2004. New Zealand horticulture facts and figures, fruit, flowers and vegetables. HortResearch, Auckland. 33 p.

Manning MA, Pak HA 1993. New insights into botrytis. New Zealand Kiwifruit April/ May: 15-18. 